\title{
INTESTINAL BACTERIA AND THE HYDROLYSIS OF GLYCOSIDIC BONDS
}

\author{
Gabrielle Hawksworth, B. S. Drasar and M. J. Hill \\ Department of Bacteriology, Wright-Fleming Institute, St Mary's Hospital \\ Medical School, Praed Street, London
}

WiTH the development of effective anaerobic techniques, the composition of the human intestinal bacterial flora is now more clearly understood. Although the detailed composition is dependent on the nature of the diet (see, for example, Hill et al., 1971), in all cases studied the predominant faecal bacteria are those of the non-sporing strictly anaerobic groups. The metabolic significance of the gut flora is only slowly emerging, but a number of review articles (e.g., Smith, 1966; Scheline, 1968) attribute to it a wide range of reactions of toxicological interest.

The involvement of intestinal bacteria in such reactions is usually inferred from indirect evidence-for example, the effect of antibiotic treatment on the metabolism of the drug, or the comparison of germ-free and conventional animals-and there are few direct studies using pure strains of bacteria. In particular, the metabolic activities of the non-sporing strictly anaerobic bacteria are virtually unknown.

Many of the enzymes concerned in the metabolism of food additives and drugs are already well known to bacteriologists. For example, the $\beta$-glucosidase responsible for the hydrolysis of aesculin and salicin is also responsible for releasing the active agents from some cardiac glycosides (Lauterbach and Repke, 1960), from cascara sagrada (Fingl, 1965) and from cycasin (Spatz, McDaniel and Laqueur, 1966).

In the process of detoxification, many compounds are conjugated by the liver to form, for example, glucuronides, and then excreted in the bile into the intestine (Smith, 1966). The glucuronides may then be hydrolysed either by enzymes of the gut mucosa or by enzymes of any bacteria present in the gut, releasing the aglycone, which may be reabsorbed and may be subsequently re-excreted by the liver into the gut.

Escherichia coli is well known to produce a $\beta$-glucuronidase (Buehler, Katzman and Doisy, 1951), but $E$. coli normally constitutes only a small proportion of the gut flora and there are no quantitative studies on the relative contributions to the glucuronidase activity of the gut contents by various bacteria. Similarly the contributions of the different bacterial species to the total activity of other glycosidases in the gut have not been assessed.

We have therefore examined the gut flora of four laboratory animals commonly used in toxicological studies and estimated the activity of the glycosidases produced by the principal groups of intestinal bacteria.

\section{MATERIALS AND METHODS}

Characterisation of the gut flora. All the animals examined were fed ad libitum-rats and mice on diet 41B (Oxoid), rabbits and guinea-pigs on diet SG1. The rats, mice and guineapigs were killed with chloroform and the rabbits by intravenous injection of air. Immediately

Received 4 Nov. 1970; accepted 25 Feb. 1971.

J. MED. MICROBIOL.-VOL. 4 (1971) 
after death the abdomen was opened and the gastro-intestinal tract was ligatured at the oesophagus, at the duodenum at a point close to the stomach, at various points along the small intestine, at the ileo-caecal junction and at the rectum. After removal of the alimentary tract, $0.5-\mathrm{g}$ amounts of the contents of the stomach and caecum were removed with sterile pasteur pipettes into $4.5-\mathrm{ml}$ volumes of glycerol broth; the latter was 1 per cent. Lab Lemco (Oxoid) broth with 10 per cent. glycerol. The same amount of material was also removed from the upper small intestine, lower small intestine and rectum by gentle pressure after cutting the gut between the ligatures. All the specimens were stored in dry ice until cultivation (Drasar and Crowther, 1970). The bacteria and yeasts present were counted by the method described by Drasar (1967).

Reagents. All reagents were obtained from Koch-Light Ltd. Acetyl digoxin was prepared from lanatoside $\mathrm{C}$ by the action of $\beta$-glucosidase (Koch-Light Ltd).

TABLE I

The growth conditions for bacteria used in enzyme assays

\begin{tabular}{|c|c|c|c|}
\hline \multirow{2}{*}{$\begin{array}{l}\text { Group of } \\
\text { bacteria tested }\end{array}$} & \multirow{2}{*}{ Culture medium } & \multicolumn{2}{|r|}{ Incubation conditions } \\
\hline & & Time (hr) & Atmosphere \\
\hline $\left.\begin{array}{l}\text { Enterobacteria } \\
\text { Enterococci }\end{array}\right\}$ & $\begin{array}{l}\text { Nutrient broth no. } 2 \text { (Oxoid) } \\
\quad+0.05 \text { per cent. lactose }\end{array}$ & 18 & Air \\
\hline Lactobacilli & $\begin{array}{l}\text { PTYE medium* }+0.05 \text { per cent. } \\
\text { lactose }\end{array}$ & 48 & $\begin{array}{l}80 \text { per cent. } \mathrm{N}_{2}+20 \text { per cent. } \\
\mathrm{CO}_{2}\end{array}$ \\
\hline $\left.\begin{array}{l}\text { Clostridia } \\
\text { Bacteroides } \\
\text { Bifidobacteria }\end{array}\right\}$ & $\begin{array}{l}\text { PTYE medium } *+0.05 \text { per cent. } \\
\text { lactose }\end{array}$ & 48 & 90 per cent. $\mathrm{H}_{2}+10$ per cent. \\
\hline
\end{tabular}

* PTYE medium $=10 \mathrm{~g}$ tryptone, $10 \mathrm{~g}$ soya peptone $+10 \mathrm{~g}$ yeast extract per litre distilled water.

Enzyme assays. Fifty strains of each of the test bacterial species were grown in 20-ml amounts of medium under the conditions described in table I. Lactose broth was used for all the assays as the $\beta$-galactosidase of some organisms (e.g., $E$. coli) is inducible and is not produced if lactose or a similar inducer is absent or if glucose is present. The addition of sucrose did not noticeably stimulate $\beta$-glucosidase activity, nor was this enzyme repressed in the presence of lactose.

The bacteria were harvested by centrifugation and $3 \mathrm{ml}$ of a washed-cell suspension in $0.025 \mathrm{M}$ phosphate buffer $(p \mathrm{H} \mathrm{7.4)}$ was used for each assay. The total number of organisms per $\mathrm{ml}$ of suspension was determined on the basis of the optical density at $600 \mathrm{~nm}$ and with reference to a standard plot of readings made for each of the test species of bacteria; the standard readings were made by direct enumeration of suspensions in a Helber counting chamber. $1 \mathrm{ml}$ of the substrate solution at a concentration of $0.2 \mathrm{mg} \mathrm{per} \mathrm{ml}$ was incubated with the bacterial suspension $(3 \mathrm{ml})$ at $37^{\circ} \mathrm{C}$ for $3 \mathrm{hr}$, or for $24 \mathrm{hr}$ when necessary (see text). The hydrolysis of $p$-nitrophenyl glycosides was assayed by the method of Kuby and Lardy (1953) and that of phenolphthalein glucuronide by the method of Fishman, Springer and Brunetti (1948).

The hydrolysis of aesculin (4,5-dihydroxycoumarin $\beta$-D-glucoside) was measured after incubation of $1 \mathrm{ml}$ of bacterial suspension containing $10^{\circ}$ bacteria with $1 \mathrm{ml}$ of a 1 per cent.

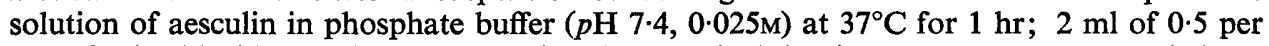
cent. ferric chloride solution was added and the optical density at $410 \mathrm{~nm}$ was recorded.

The cardiac glycoside, lanatoside $\mathrm{C}$, was used as a further substrate for bacterial $\beta$-glucosidase. Bacterial suspensions were incubated with lanatoside $\mathrm{C} 0.5 \mathrm{mg} \mathrm{per} \mathrm{ml}$ at $37^{\circ} \mathrm{C}$ 
and $p \mathrm{H} 7.4$ for $16 \mathrm{hr}$. The products were separated from the substrate by thin-layer chromatography on plates of silica gel G (Merck) subsequently developed with a mixture of hexane,

TABLE II

The composition of the intestinal flora of four laboratory animal species and man

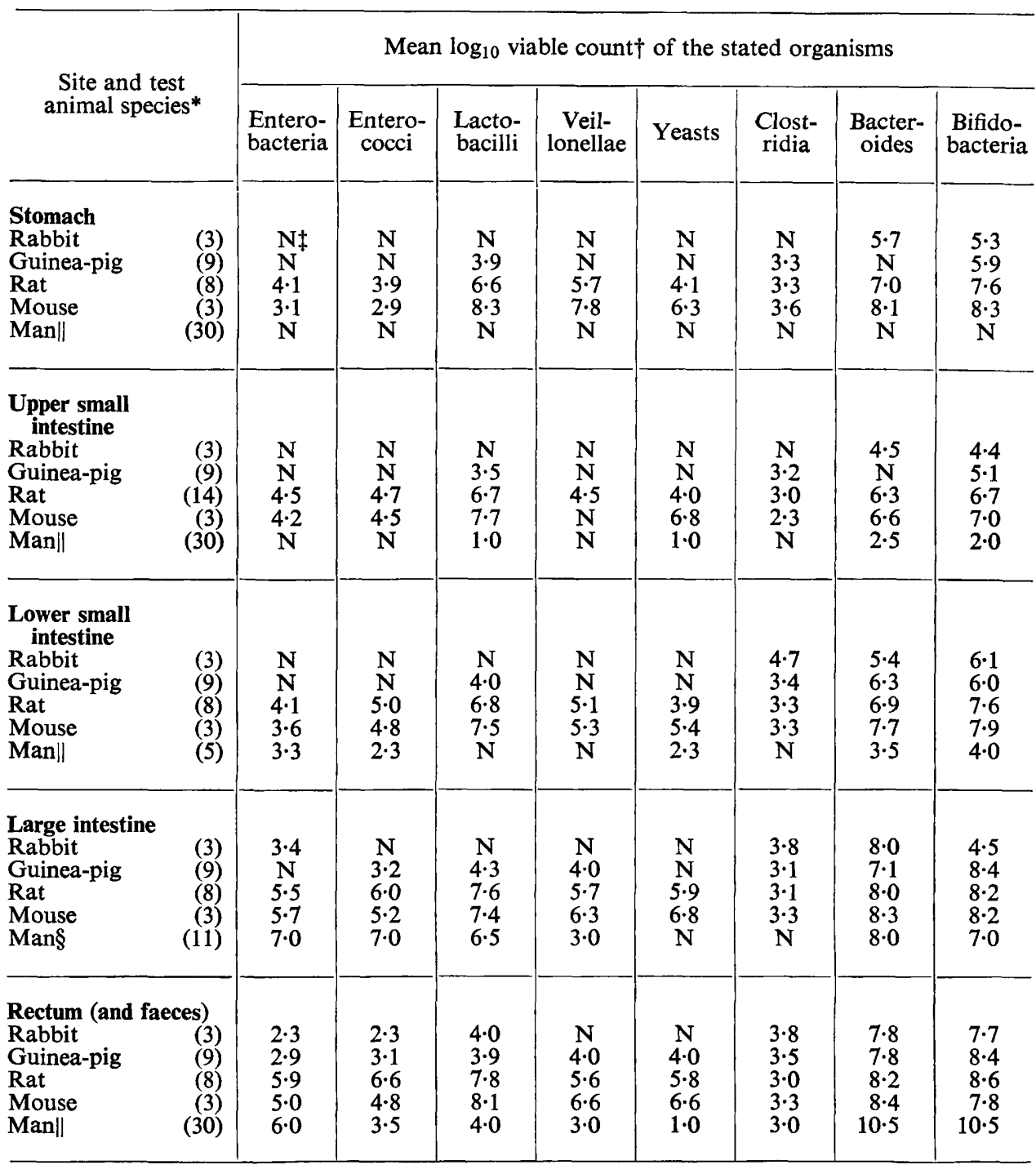

* The number tested is given in brackets.

+ The figures are the mean $\log _{10}$ viable count per $g$ wet weight of test material.

$\$ \mathbf{N}=$ less than 10 organisms per $\mathbf{g}$ wet weight of test material (see Methods).

$\S$ After Seeliger and Werner (1963).

II From Drasar, Shiner and McLeod (1969)

ethyl acetate and ethanol $(15: 75: 10 \mathrm{v} / \mathrm{v})$ (Nover et al., 1969). Enzyme activity was estimated semiquantitatively by locating the products as blue spots with a 10 per cent. solution of phosphomolybdic acid in ethanol. 


\section{RESULTS \\ Intestinal flora of the laboratory animals}

The results of our studies on the composition of the normal bacterial flora of the intestine of the rat, mouse, guinea-pig and rabbit are summarised in table II. For comparison, the normal intestinal flora of healthy persons investigated by Drasar, Shiner and MacLeod (1969) is indicated.

Rats and mice are coprophagic and so ingest large numbers of bacteria. These animals have large numbers of bacteria along the whole length of the gastro-intestinal tract. In the stomach and small intestine the most numerous organisms are lactobacilli, Bacteroides species and bifidobacteria; these organisms outnumber the enterobacteria (mainly Escherichia coli) by a factor of more than $10^{2}$. In contrast, the stomach and small intestine of the rabbit and guinea-pig contain a very simple flora, similar to that of man, and the total number of bacteria is much lower than in the mouse and rat.

In the large intestine a more complex and profuse flora is present in all four animal species. The principal groups of bacteria present are the enterobacteria (mainly E. coli), enterococci, lactobacilli, Bacteroides species and bifidobacteria; in all the animals the strictly anaerobic bacteria (bacteroides and bifidobacteria) greatly outnumber the aerobes (enterobacteria and enterococci), with lactobacilli present in very large numbers in the rat and mouse, and in smaller numbers in the rabbit, guinea-pig and man.

\section{Enzyme activity of gut bacteria}

Pure cultures of 50 strains representing six groups of bacteria-E. coli, enterococci, lactobacilli, Nagler-positive clostridia, Bacteroides species and bifidobacteria-were assayed for the production of $\beta$-glucuronidase, $\alpha-$ and $\beta$-glucosidases and $\alpha$ - and $\beta$-galactosidases. The results of the assays involving nitrophenyl substrates are presented as a series of histograms (figure) and the mean values, expressed as $\mu$ moles nitrophenol released per $\mathrm{hr}$ per $10^{8}$ bacteria, are given in table III. Enterococci produce large amounts of $\beta$-glucosidase and $\beta$-galactosidase, but little $\beta$-glucuronidase, whereas $E$. coli produces large amounts of $\beta$-glucuronidase and $\beta$-galactosidase, but little $\beta$-glucosidase. The non-sporing anaerobes produce intermediate amounts of all of these enzymes except $\beta$-glucuronidase.

$\beta$-glucuronidase was produced in greatest amount by $E$. coli; the Naglerpositive clostridia and Bacteroides species produced an intermediate amount of this enzyme, and the enterococci, lactobacilli and bifidobacteria produced very little.

Similar results were obtained with phenolphthalein substrates and with aesculin as a substrate for $\beta$-glucosidase. The cardiac glycoside, lanatoside $\mathrm{C}$, was hydrolysed to acetyl digoxin by more of the enterococci than of the other species. Some enterococcal strains also degraded this secondary glycoside, removing the O-acetyl group and yielding digoxin. 


\section{DISCUSSION}

The extent to which compounds, whether ingested or excreted in the bile, are metabolised by gut bacteria depends on at least three factors-(i) the
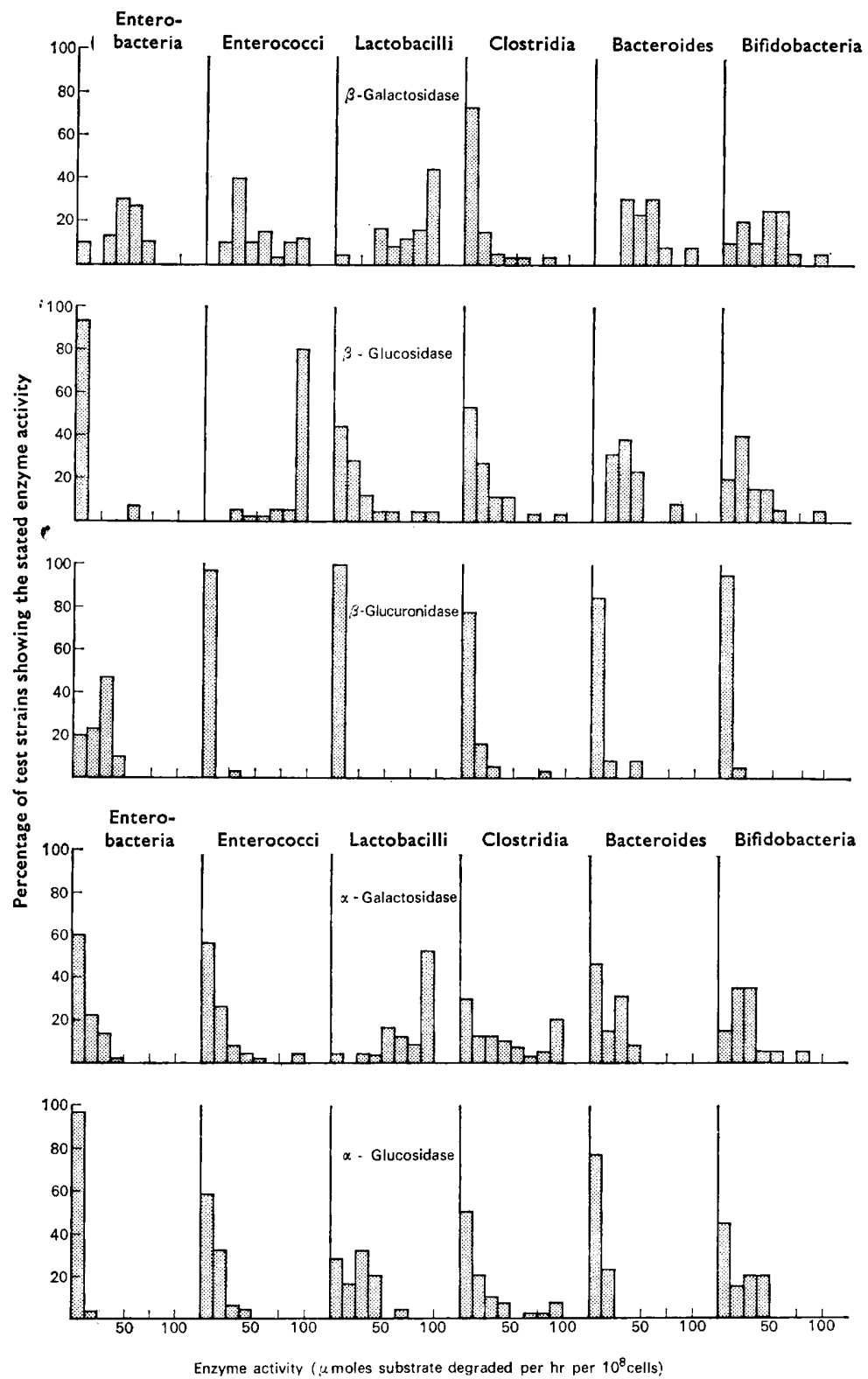

FIGURE.-A comparison of the various enzyme activities of 50 test strains representing six different groups of intestinal bacteria.

region of the gut from which the compound is absorbed; (ii) the distribution of bacteria along the gut; and (iii) the occurrence of the necessary enzyme or 
enzyme system in the bacteria. The principal site of absorption of hydrolysed compounds is the small intestine, and this region of the gut is much less heavily colonised in man and the rabbit than in the other animals tested, so that compounds are less likely to be degraded by bacteria in the human or rabbit gut than in the gut of the rat or mouse.

In the rabbit, the $p \mathrm{H}$ value of the stomach contents is normally sufficiently low to be bacteriostatic and sometimes low enough to be bactericidal (Smith, 1965). In guinea-pigs that have been actively feeding, the $p \mathrm{H}$ of the stomach contents (mean 3.5) is high enough to allow the growth of lactobacilli and

TABLE III

Mean activity of the glycosidases of the principal species of gut bacteria

\begin{tabular}{|c|c|c|c|c|c|c|}
\hline \multirow{2}{*}{$\begin{array}{l}\text { Enzyme } \\
\text { assayed }\end{array}$} & \multicolumn{6}{|c|}{$\begin{array}{l}\text { Mean value ( } \mu \text { moles substrate degraded per hr per } 10^{8} \text { cells) for } 50 \text { test strains } \\
\text { in each of the stated groups }\end{array}$} \\
\hline & $\begin{array}{l}\text { Entero- } \\
\text { bacteria }\end{array}$ & Enterococci & Lactobacilli & Clostridia & Bacteroides & $\begin{array}{r}\text { Bifido- } \\
\text { bacteria }\end{array}$ \\
\hline$\beta$-Galactosidase & $42 \cdot 4 \pm 3 \cdot 2^{*}$ & $53 \cdot 8 \pm 6 \cdot 0$ & $90 \cdot 6+10 \cdot 7$ & $13 \cdot 7 \pm 2 \cdot 7$ & $50 \cdot 7 \pm 4 \cdot 9$ & $39 \cdot 1 \pm 4 \cdot 7$ \\
\hline$\beta$-Glucosidase & $5 \cdot 8 \pm 2 \cdot 5$ & $192 \cdot 7 \pm 19 \cdot 5$ & $26 \cdot 0 \pm 7 \cdot 4$ & $22 \cdot 1 \pm 5 \cdot 0$ & $35 \cdot 1 \pm 4 \cdot 8$ & $29 \cdot 3 \pm 6 \cdot 0$ \\
\hline$\beta$-Glucuronidase & $24 \cdot 7 \pm 2 \cdot 1$ & $2.9 \pm 0.6$ & $1 \cdot 6 \pm 0.2$ & $11 \cdot 3 \pm 2 \cdot 3$ & $6 \cdot 0 \pm 3 \cdot 5$ & $1.9 \pm 0.8$ \\
\hline$\alpha$-Galactosidase & $12 \cdot 7 \pm 2 \cdot 1$ & $20 \cdot 8 \pm 4 \cdot 3$ & $97 \cdot 7 \pm 12 \cdot 1$ & $53 \cdot 1 \pm 8 \cdot 1$ & $24 \cdot 0 \pm 4 \cdot 8$ & $28 \cdot 2 \pm 3 \cdot 8$ \\
\hline$\alpha$-Glucosidase & $5.9 \pm 0.5$ & $14 \cdot 0 \pm 1 \cdot 1$ & $26 \cdot 6 \pm 3 \cdot 5$ & $30 \cdot 1 \pm 6 \cdot 4$ & $9 \cdot 8 \pm 2 \cdot 0$ & $20.7 \pm 3.0$ \\
\hline
\end{tabular}

* The standard error of the mean is given in each case.

bifidobacteria (the organisms least affected by acid conditions), but rats and mice secrete much less gastric acid, so that the ingested flora is not destroyed and there is considerable evidence for multiplication of bacteria in the mouse stomach (Dubos et al., 1965). In the rat and mouse there is a constant flow of bacteria into the intestine, which may partly account for its being more heavily populated than the intestine of the rabbit, guinea-pig or man.

Glucuronide formation is a major detoxification mechanism in animals, and it is probable that glucuronides excreted in the bile are deconjugated by bacterial $\beta$-glucuronidase. For example, there is evidence that stilboestrol glucuronide is hydrolysed mainly by the action of bacterial enzymes in the gut (Dr Millburn, personal communication).

An approximate estimate of the total $\beta$-glucuronidase activity derived from each group of bacteria can be made by multiplying the mean activity observed per cell by the number of the bacteria present, assuming that the bacterial enzymes of the different species have the same potential activity in the intestine as that observed in vitro. The results of such a calculation (table IV) suggest that, in the rat, glucuronides are hydrolysed principally by the non-sporing 
anaerobes and the lactobacilli, although in the proximal small intestine Escherichia coli may make some contribution. A similar calculation reveals

TABLE IV

Estimated bacterial $\beta$-glucuronidase activity in the small intestine of the rat

\begin{tabular}{|c|c|c|c|c|c|}
\hline \multirow{2}{*}{$\begin{array}{l}\text { Test group of } \\
\text { bacteria }\end{array}$} & \multirow{2}{*}{$\begin{array}{l}\text { Mean activity } \\
\text { per } 10^{8} \text { cells* }\end{array}$} & \multicolumn{2}{|c|}{$\begin{array}{l}\text { Estimates for proximal } \\
\text { small intestine }\end{array}$} & \multicolumn{2}{|c|}{$\begin{array}{l}\text { Estimates for distal } \\
\text { small intestine }\end{array}$} \\
\hline & & $\begin{array}{c}\text { Number of } \\
\text { bacteria }\end{array}$ & Total activity $\dagger$ & $\begin{array}{c}\text { Number of } \\
\text { bacteria }\end{array}$ & Total activity $\dagger$ \\
\hline $\begin{array}{l}\text { Enterobacteria } \\
\text { Enterococci } \\
\text { Lactobacilli } \\
\text { Clostridia } \\
\text { Bacteroides } \\
\text { Bifidobacteria }\end{array}$ & $\begin{array}{r}24 \cdot 7 \\
2 \cdot 9 \\
1 \cdot 6 \\
11 \cdot 3 \\
6 \cdot 0 \\
1 \cdot 9\end{array}$ & $\begin{array}{l}3 \cdot 2 \times 10^{4} \\
5 \cdot 0 \times 10^{4} \\
5 \cdot 0 \times 10^{6} \\
1 \cdot 0 \times 10^{3} \\
2 \cdot 0 \times 10^{6} \\
5 \cdot 0 \times 10^{6}\end{array}$ & $\begin{array}{r}7.9 \\
1.5 \\
80 \cdot 0 \\
0 \cdot 1 \\
120 \cdot 0 \\
95 \cdot 0\end{array}$ & $\begin{array}{l}1.3 \times 10^{4} \\
1 \cdot 0 \times 10^{5} \\
6 \cdot 3 \times 10^{6} \\
2 \cdot 0 \times 10^{3} \\
7 \cdot 9 \times 10^{6} \\
4.0 \times 10^{6}\end{array}$ & $\begin{array}{r}3 \cdot 2 \\
2 \cdot 9 \\
101 \cdot 0 \\
0 \cdot 2 \\
474 \cdot 0 \\
760 \cdot 0\end{array}$ \\
\hline $\begin{array}{l}\text { Cumulative total } \\
\text { estimate of } \beta- \\
\text { glucuronidase } \\
\text { activity }\end{array}$ & $\ldots$ & $\ldots$ & 304 & .. & 1341 \\
\hline
\end{tabular}

* See table III.

$\dagger \mu$ moles substrate degraded per hr per $\mathrm{g}$ intestinal contents.

that although the enterococci are the organisms that produce the highest level of $\beta$-glucosidase per cell, the organisms most likely to be responsible for hydrolysis in the small intestine of the rat are again the strict anaerobes.

TABLE V

Estimated bacterial $\beta$-glucuronidase activity in the small intestine of man and four laboratory animal species

\begin{tabular}{l|c|c}
\hline \multirow{2}{*}{$\begin{array}{c}\text { Animal } \\
\text { species }\end{array}$} & \multicolumn{2}{|c}{ Estimated $\beta$-glucuronidase activity* } \\
\cline { 2 - 3 } & $\begin{array}{c}\text { in proximal } \\
\text { small intestine }\end{array}$ & $\begin{array}{c}\text { in distal } \\
\text { small intestine }\end{array}$ \\
\hline Man & $0 \cdot 02$ & $0 \cdot 9$ \\
Rabbit & $2 \cdot 4$ & $45 \cdot 4$ \\
Guinea-pig & $2 \cdot 7$ & 139 \\
Rat & 304 & 1341 \\
Mouse & 1200 & 5015 \\
\hline
\end{tabular}

* $\mu$ moles substrate degraded per $\mathrm{hr}$ per $\mathrm{g}$ intestinal contents.

The level of $\beta$-glucuronidase activity in the small intestine of man, rabbit and guinea-pig is very low compared with that observed in the rat (table V). This is in agreement with the results of Marsh, Alexander and Levvy (1952), 
who showed that the $\beta$-glucuronidase activity of ileal contents of the rat was 15 times greater than that of the ileal contents of the rabbit. This suggests that hydrolysis, and therefore hepatic recycling, of glucuronides occurs much more extensively in the small intestine of the rat and mouse (the animals most commonly used in toxicological studies) than in man.

\section{SUMMARY}

As part of a study of the metabolic activities of intestinal bacteria, the activity of the principal glycosidases produced by the major groups of intestinal bacteria has been estimated. The results are discussed in terms of the toxicological and pharmacological effects of various ingested glycosides and of the enterohepatic circulation of compounds by four laboratory animal species commonly used in toxicological studies.

We are indebted to the British Nutrition Foundation for their financial support, and to the staff of the Biochemistry Department of St Mary's Hospital Medical School for their helpful advice.

\section{REFERENCES}

Buehler, H. J., Katzman, P. A., AND Doisy, E. A. 1951. Studies on $\beta$-glucuronidase from E. coli. Proc. Soc. Exp. Biol. Med., 76, 672.

Drasar, B. S. 1967. Cultivation of anaerobic intestinal bacteria. J. Path. Bact., 94, 417.

DraSAR, B. S., AND CROWTHER, J. S. 1971. Cultivation of human intestinal bacteria. Soc. Applied Bact. Techn. Ser. no. 5: Isolation of anaerobes, p. 93.

Drasar, B. S., Shiner, Margot, AND McLeod, G. M. 1969. Studies on the intestinal flora. 1. The bacterial flora of the gastrointestinal tract in healthy and achlorhydric persons. Gastroenterology, 56, 71.

Dubos, R., Schaedler, R. W., Costello, R., and Hoet, P. 1965. Indigenous " normal " and autochthonous flora of the gastrointestinal tract. J. Exp. Med., 122, 67.

FinGL, E. 1965. In The pharmacological basis of therapeutics, 3rd ed., edited by L. S. Goodman and A. Gilman, New York.

Fishman, W. H., SpRINGer, B., AND BRUNetTI, R. 1948. Application of an improved glucuronidase assay method to the study of human blood $\beta$-glucuronidase. J. Biol. Chem., 173, 449.

Hill, M. J., Crowther, J. S., Drasar, B. S., Hawksworth, Gabrielle, Aries, VivienNe, AND WilLIAMS, R. E. O. 1971. Bacteria and aetiology of cancer of large bowel. Lancet, 1,95 .

KuBY, S. A. AND LARDY, H. A. 1953. Purification and kinetics of $\beta$-D-galactosidase from Escherichia coli, strain K-12. J. Amer. Chem. Soc., 75, 891.

LAUTERBACH, F., AND REPKE, K. 1960. On the distribution of cardiac glycoside splitting enzymes in the animal body. Arch. Exp. Path. Pharmak., 240, 45 (in German).

Marsh, C. A., AleXANDER, F., AND LeVvy, G. A. 1952. Glucuronide decomposition in the digestive tract. Nature, Lond., 170, 163.

Nover, L., JÜttNer, G., NoaCK, S., BaumGarten, G., AND LuCKNer, M. 1969. Über die Beziehungen zwischen chemischer Struktur und chromatographischem Verhalten bei Herzglykosiden. V. Mitteilung Dünnschichtchromatographische Untersuchungen an Herzglykosiden und ihren Geninen. J. Chromat., 39, 419.

SCHELINE, R. R. 1968. Drug metabolism by intestinal microorganisms. J. Pharm. Sci., 57, 2021.

Seeliger, H. P. R., AND WeRner, H. 1963. Recherches qualitatives et quantitatives sur la flore intestinale de l'homme. Annls Inst. Pasteur, Paris, 105, 911. 
SмIтH, H. W. 1965. Observations on the flora of the alimentary tract of animals and factors affecting its composition. J. Path. Bact., 89, 95.

Sмith, R. L. 1966. The biliary excretion and enterohepatic circulation of drugs and other organic compounds. Prog. Drug Res., 9, 299.

Spatz, M., McDaniel, E. G., AND LaQueur, G. L. 1966. Cycasin excretion in conventional and germfree animals. Proc. Soc. Exp. Biol. Med., 121, 417. 